\title{
Regional Imbalance in the Service Level Benchmarking of Urban Local Bodies (UBLS) in Karnataka
}

\author{
Shiddalingaswami V Hanagodimath*and Tigiripalli \\ Bramhanandam ${ }^{\dagger}$
}

\section{Abstract:}

In India urbanisation has increased from 27.81 per cent in 2001 to 31.16 per cent in 2011. The same trend has even continued in Karnataka also i.e. from 34 per cent in 2001 to 38.57 per cent in 2011. As Urban Local Bodies [ULBs] are the major service providers in urban areas, the disparities in their income, expenditure, and functional abilities are an index of regional disparities (HPCFRRI, 2002). The role of urban local bodies cannot be ignored. Hence, this study considers regional imbalance in the service level benchmarking of urban local bodies (ubls) in Karnataka. The result of the study shows that North Karnataka in general and Hyderabad Karnataka in particular are under developed in urban service level benchmarking alike the most of the sectors in the state. Hence, special attention is to be paid for this region both in planning and allocation of money. This study suggests that more powers should be given to Urban Local Bodies and its elected representatives. Further, a monitoring mechanism should be set up in lower performing sectors so that targets can be achieved.

Keywords: Regional imbalance, UBLs, Karnataka, Index, Expenditure

\footnotetext{
* Assistant Professor, Centre for Multi-disciplinary Development Research (CMDR), Dr. B. R. Ambedkar Nagar, Yalakki Shetter Colony, Dharwad Karnataka, 580004 - India shiddu22@gmail.com
}

$\dagger$ Associate Professor, (CMDR), Dharwad, Karnataka, India; tramayya@cmdr.ac.in 


\section{Introduction:}

In a developing country like India, seasonal employment, disguised unemployment, surplus labour in agriculture sector and lack of innovativeness in income and employment generating activities coupled with rigid a social structure are a common phenomenon in the rural areas. Hence urbanisation has become a very important tool for development. The $21^{\text {st }}$ century is considered to be an urban oriented century. Cities are the engines of growth, as they contribute more than 60 per cent of the GDP. Most of the people are attracted to cities due to better quality of life, good service delivery mechanism in water, Sewerage, Transport and Open spaces. Cities are also endowed with good education and health facilities compared to villages. Consequently, the migration from rural to urban areas has become a significant phenomenon. According to World Urbanization Prospects by UN DESA's Population Division, 54 per cent (3.9 billion) of the world's population lives in urban areas, a proportion that is expected to increase to 66 per cent by 2050. This has also estimated that the largest urban growth will take place in India, China and Nigeria. These three countries will account for 37 per cent of the projected growth of the world's urban population between 2014 and 2050. By 2050, India is projected to add 404 million urban dwellers, China 292 million and Nigeria 212 million.

In India urbanisation has increased from 27.81 per cent in 2001 to 31.16 per cent in 2011. The same trend has even continued in Karnataka alsoi.e. from 34 per cent in 2001 to 38.57 per cent in 2011. Increasing urbanisation has brought many problems and challenges to the policy makers at the state level. Chand classifies major problems of urbanisation in India as 1. Urban Sprawl 2. Overcrowding 3. Housing 4. Unemployment 5. Slums and Squatter Settlements 6. Transport 7. Water 8. Sewerage Problems 9. Trash Disposal 10. Urban Crimes 11. Problem of Urban Pollution.

As Urban Local Bodies [ULBs] are the major service providers in urban areas, the disparities in their income, expenditure, and functional abilities are an index of regional disparities (HPCFRRI, 2002). The role of urban local bodies cannot be ignored. Hence, government of India gives ranks to all the urban local bodies through the construction of an index named as Urban Service Level 
Benchmarking. This exercise has been taken up because investment in infrastructure has not resulted in a way they were targeted. Further, not only infrastructure but also the service delivery mechanism should be improved for the development of the urban local bodies and the standard of living of the urban people.

Regional imbalancei is a common phenomenon faced by every country/state. The same imbalances are also visible in all the sectors of Karnataka. Similarly, urban sector is not an exception. There are numerous studies on regional imbalances in Karnatakaii in the recent times (See among others Dadibhavi (1982),Kadekodi, Kanbur and Rao et (2008), Panchamukhi (2001), Shiddalingaswami and Ragavendra (2010), Deshpande and Dadibhavi (2005), Siddu and Aziz (2012), Degaonkar (2014), Dadibhavi (1998), Degaonkar (2001), Deshpande (2014), Chandrashekar (2009), Chandrashekar (2014), Chandrashekar and Nagaraju. (1999), Dadibhavi (1998), Gayatri (2012),Hanagodimath (2014). But focused studies on urban issues are few. Regional imbalances in urban service mechanism can be studied by using the data from urban service level benchmarking. Methodology of the same is discussed below.

\section{Methodology of Service level benchmarking}

Using 49 indicators from 7 different sectors, benchmarking has been calculated for a total of 540 marks. The indicators/benching have been presented in the following box. Please refer to Handbook of Service Level Benchmarking, Ministry of Urban Development, Government of India for more information on service level benchmarking

\section{List of benchmarking (49 Indicators from 7 Sectors)}

\section{Water Supply System (12)}

Per capita production of water, Number of days of water supply per week (Normal season), Number of hours of water supply in a day (Normal season), Household connection coverage, Service Coverage in Slums, \% of Surface water treated before supply, Quality of water supply, Cost recovery in water supply services, Extent of working metered water connection to all categories, Efficiency in redressal of customer complaint, Collection Efficiency 
(Water Charges for Current Year), Collection Efficiency (Arrears of water charges)

\section{Waste Water Management (6)}

$\%$ of $\mathrm{HH}$ with Sewerage connection, Collection efficiency of waste water, \% of Waste Water Treated, Extent of reuse and recycle of treated waste water, Extent of cost recovery in waste water management, Efficiency in redressal of customer complaint

\section{Solid Waste Management (10)}

MSW Collection Efficiency, \% households under door to door collection, \% of Road Length cleaned per day, Vehicle Adequacy Ratio, Treatment Efficiency, Cost per ton of solid waste management (collected \& Disposed), Extent of segregation of MSW, Extent of scientific disposal of MSW, Extent of cost recovery in SWM, Efficiency in redressal of customer complaint

\section{Roads, Road side drains and Streetlights (7)}

$\%$ Road side drains to road length, \% all weather Road length, Number of Street Lights per Km of Road Length, Maintenance Expenditure per $\mathrm{km}$ of road length, Operation and Maintenance cost per street light, Incidence of water logging and flooding, Efficiency in redressal of customer complaint

\section{Disease Control (2)}

Number of vector borne disease cases per 1000 population, Number of water borne disease cases per 1000 population

\section{Development of Parks \& Gardens (2)}

$\%$ of area under parks and gardens, $\%$ of areas of developed parks and gardens

\section{Finance (10)}

Property Coverage ratio, Collection Efficiency (Property Tax) Current Year, Collection Efficiency (Property Tax) Arrears, Per capita gross own revenue receipts, Per capita tax receipts, Per capita own non tax receipts, Per capita expenditure, 18\% utilization (ob+ current year), Income per Employee... (Rs.), Expense per Employee... (Rs.) 
Given this background, the present paper has the objective to analyse the region, division and district wise status of ULBs in service level benchmarking in the state of Karnataka and its relationship with per capita income.

The present paper has been divided into six sections, after the introduction, section two analyses region and division wise status in different service level benchmarking. Section three is devoted to district level analyses, while section four is on the performance of different types of ULBs. In fifth section relationship among and between different indicators are traced and the last section provides concluding remarks for the paper.

\section{Region and Division wise performance:}

Based on the data available at different levels of ULBs in Karnataka Urban Service Level Benchmarking Ranking Report for the year 20092010averages have been calculated for each region, division and district to see their performance in different sectors. Average performance of different ULBs in different sectors have been presented in table 1 . In the table, maximum score as well as obtained score for different sectors are presented for all the administrative divisions of the north and the south regions. It is found that the average mark of the state is 210 out of the maximum marks of 540. It means only 39 per cent of bench marking has been achieved in the state. Among the different sectors, benchmarking is good in Roads, Roadside Drains \& Streetlights (45 marks with 50\%) and Municipal Finance (50 marks with 50\%). Water supply (48 marks with $48 \%$ ) and solid waste management (60 marks with $40 \%$ ) with Municipal Finance (50 marks and 50\%) showing good performance comparatively. Lower performance is observed in the sectors like Waste Water Management (3 marks with 6\%) and Development of Parks \& Gardens (4 marks with 15\%). In Disease Control out of 25 marks noneof the ULBs have got any score in the state. 
Table 1: Division and Region wise Urban Service Level benchmarking, 2009-2010 (Average)

\begin{tabular}{|c|c|c|c|c|c|c|c|c|}
\hline 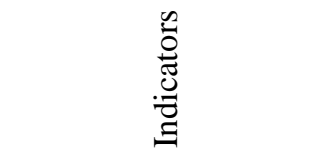 & 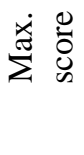 & $\begin{array}{l}\Xi \\
\Xi \\
\bar{\Xi} \\
\frac{\Phi}{\infty} \\
\infty\end{array}$ & 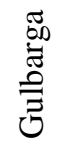 & 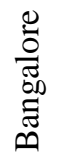 & $\begin{array}{l}\stackrel{0}{0} \\
\stackrel{\infty}{\infty} \\
\sum\end{array}$ & $\begin{array}{l}\text { Ẽ } \\
\text { Z }\end{array}$ & $\begin{array}{l}\bar{\Xi} \\
\stackrel{\Xi}{0} \\
\stackrel{n}{n}\end{array}$ & 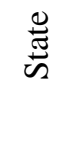 \\
\hline $\begin{array}{l}\text { Water Supply } \\
\text { Management }\end{array}$ & 100 & 48 & 42 & 44 & 54 & 46 & 49 & 48 \\
\hline $\begin{array}{l}\text { Waste Water } \\
\text { Management }\end{array}$ & 50 & 3 & 1 & 2 & 5 & 2 & 4 & 3 \\
\hline $\begin{array}{l}\text { Solid Waste } \\
\text { Management }\end{array}$ & 150 & 65 & 51 & 57 & 61 & 60 & 59 & 60 \\
\hline $\begin{array}{l}\text { Roads, Roadside } \\
\text { Drains \& Streetlights }\end{array}$ & 90 & 46 & 39 & 45 & 49 & 44 & 47 & 45 \\
\hline Disease Control & 25 & 0 & 0 & 0 & 0 & 0 & 0 & 0 \\
\hline $\begin{array}{l}\text { Development } \\
\text { of Parks \& Gardens }\end{array}$ & 25 & 3 & 3 & 4 & 6 & 3 & 5 & 4 \\
\hline Municipal Finance & 100 & 51 & 41 & 50 & 55 & 47 & 53 & 50 \\
\hline Total Marks & 540 & 217 & 177 & 204 & 230 & 202 & 217 & 210 \\
\hline
\end{tabular}

Source: Computed from the data available on http://karbenchmarking.gov.in

In overall service level benchmarking, southern region is in a better-off condition with 217 marks as compared to the northern region which has scored 202 marks. Further, south Karnataka is in a good position in all the sectors except Solid Waste Management, where the north has scored higher marks (1mark more) than the south. Among the divisions, Mysore division stands in the first position with an average mark of 230 followed by Belgaum (217 marks) and Bangalore (204 marks). Lowest marks were obtained by Gulbarga (177) division. Except in Solid Waste Management in all the other sectors Mysore division retained the first position. Gulbarga stands at the lowest position in all seven sectors.

Another excise has been made to see the inter-ULB variations/imbalances of different division of both the regions of the state. For this purpose Coefficient of variation has been calculated and presented in table 2. It is found that among the sectors, Waste Water Management (207) has the highest inter-ULB variations in benchmarking followed by Development of Parks $\mathcal{E}$ Gardens (137). Between the regions it is found that both south and 
north have the similar inter-ULB variation in benchmarking. Northern region has huge inter-ULB imbalances in Waste Water Management and Development of Parks \& Gardens as compared with the southern region. Among the divisions, Mysore division has the highest imbalance followed by Gulbarga and Bangalore. The lowest imbalanceis observed in Belgaum division. All the divisions have higher inter-ULB variation in Waste Water Management and Development of Parks $\mathcal{E}$ Gardens.

Table 2: Division and Region wise Inter-ULB Variations in Urban Service Level Benchmarking (CV-\%)

\begin{tabular}{|c|c|c|c|c|c|c|c|}
\hline 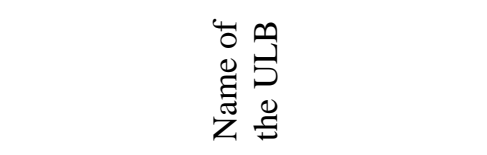 & 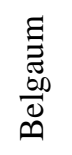 & 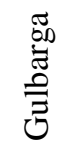 & 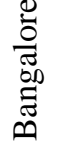 & 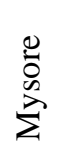 & 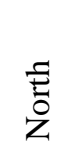 & 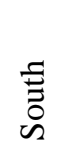 & 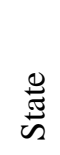 \\
\hline Water Supply Management & 24 & 30 & 34 & 24 & 27 & 30 & 29 \\
\hline Waste Water Management & 205 & 282 & 223 & 163 & 227 & 190 & 207 \\
\hline Solid Waste Management & 24 & 30 & 18 & 32 & 28 & 27 & 27 \\
\hline $\begin{array}{l}\text { Roads, Roadside Drains } \\
\text { \&streetlights }\end{array}$ & 19 & 30 & 19 & 21 & 24 & 21 & 23 \\
\hline Development of Parks \& Gardens & 173 & 146 & 128 & 107 & 162 & 117 & 137 \\
\hline Municipal Finance & 33 & 45 & 31 & 32 & 38 & 32 & 35 \\
\hline Total Marks & 16 & 18 & 17 & 20 & 19 & 19 & 19 \\
\hline
\end{tabular}

Source: Computed from the data available on http://karbenchmarking.gov.in

\section{District Wise Performance:}

Table 3 reveals district wise urban service level benchmarking. It is observed that out of 540 marks, Udupi district has obtained an average of 299 marks, which is the maximum among all the districts. The lowest score of 158 is observed in Yadgir district. The gap between the highest marks and the lowest marks is nearly double.Except U. Kannada all the top 5 performing districts are from southern region. Further, out of them three districts namely, Udupi, Mysore, D Kannada are from Mysore division and only one district Shimoga is from Bangalore division. Among the bottom performing five districts, three districts are from Gulbarga division (Yadgir, Bidar and Gulbarga) and two are from Bangalore division (Kolar and Bangalore Urban), none of the districts are either from 
Mysore division or from Belgaum division in this regard. Totally, more number of districts of south Karnataka are in the top position in general and the districts of Mysore division in particular, whereas the districts of north Karnataka are in the bottom position in general and the districts of Gulbarga division in particular are in a low position.

\section{Some Observations:}

- Even though, Shimoga is in the second position in overall benchmarking, its performance is not satisfactory in Waste Water Management (19 ${ }^{\text {th }}$ rank) and Solid Waste Management (10 th rank).

- In overall benchmarking Chamarajanagar is in the $25^{\text {th }}$ rank, nevertheless its performance in Waste Water Management $\left(7^{\text {th }}\right.$ rank) is quite good.

- Due to lower performance in parameterslike Development of Parks $\mathcal{E}$ Gardens (11 th rank) and Municipal Finance (12 ${ }^{\text {th }}$ rank), Mysore district has been pushed into the third position instead of second position.

- Hassan ( $1^{\text {st }}$ position) and Bagalkot ( $3^{\text {rd }}$ position) districts have shown good performance in Waste Water Management, even though their rankings are $11^{\text {th }}$ and $15^{\text {th }}$ respectively in the overall benchmark.

- In overall benchmarking Yadgir was found to be in the bottom position, but its performance in Development of Parks $\mathcal{E}$ Gardens is comparatively good with $12^{\text {th }}$ rank.

- None of the districts from Hyderabad Karnataka are found either in top 5 or even in 10 positions among the 30 districts of Karnataka. 
Table 3: District wise Urban Service Level Benchmarking, 2009-2010 (Average)

\begin{tabular}{|c|c|c|c|c|c|c|c|c|c|}
\hline 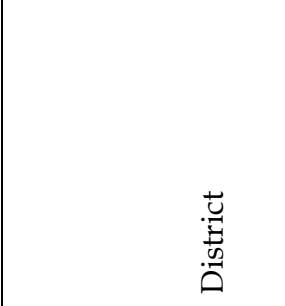 & 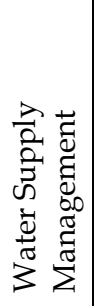 & 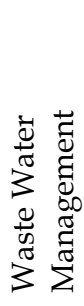 & 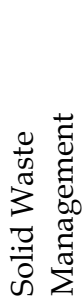 & 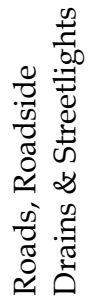 & 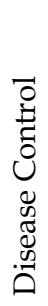 & 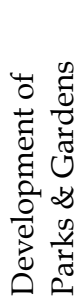 & 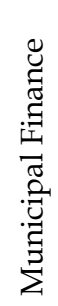 & 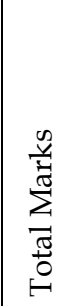 & 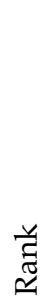 \\
\hline Udupi & 66 & 5.5 & 91 & 50 & 0 & 8.5 & 79 & 299 & 1 \\
\hline Shimoga & 62 & 1.8 & 60 & 54 & 0 & 5.2 & 58 & 240 & 2 \\
\hline Mysore & 57 & 6.7 & 70 & 49 & 0 & 4.4 & 51 & 238 & 3 \\
\hline Dakshina Kannada & 62 & 2.6 & 56 & 49 & 0 & 6.3 & 60 & 236 & 4 \\
\hline Uttara Kannada & 46 & 2.7 & 68 & 52 & 0 & 6.0 & 61 & 235 & 5 \\
\hline Chikkamagalore & 50 & 1.3 & 68 & 55 & 0 & 6.4 & 53 & 233 & 6 \\
\hline Dharwad & 54 & 3.7 & 75 & 46 & 0 & 1.3 & 50 & 230 & 7 \\
\hline Belgaum & 53 & 1.8 & 64 & 51 & 0 & 1.7 & 55 & 227 & 8 \\
\hline Ramanagara & 53 & 3.5 & 67 & 47 & 0 & 3.0 & 54 & 227 & 9 \\
\hline Kodagu & 49 & 0.0 & 52 & 58 & 0 & 2.0 & 67 & 227 & 9 \\
\hline Hassan & 50 & 13.5 & 54 & 46 & 0 & 2.5 & 57 & 222 & 11 \\
\hline Mandya & 57 & 5.6 & 51 & 44 & 0 & 11.9 & 48 & 217 & 12 \\
\hline Davanagere & 58 & 3.2 & 58 & 44 & 0 & 3.3 & 52 & 217 & 13 \\
\hline Gadag & 42 & 2.0 & 67 & 45 & 0 & 6.6 & 49 & 212 & 14 \\
\hline Bagalkot & 49 & 5.8 & 59 & 44 & 0 & 1.3 & 45 & 204 & 15 \\
\hline Bijapur & 47 & 3.3 & 74 & 37 & 0 & 0.0 & 42 & 203 & 16 \\
\hline Tumkur & 45 & 1.8 & 54 & 44 & 0 & 4.6 & 47 & 197 & 17 \\
\hline Bangalore Rural & 25 & 2.0 & 57 & 47 & 0 & 3.2 & 62 & 196 & 18 \\
\hline Haveri & 43 & 2.8 & 57 & 40 & 0 & 2.4 & 51 & 196 & 19 \\
\hline Raichur & 54 & 1.7 & 52 & 39 & 0 & 2.0 & 46 & 195 & 20 \\
\hline Chitradurga & 40 & 1.2 & 57 & 43 & 0 & 3.3 & 44 & 188 & 21 \\
\hline Bellary & 46 & 2.8 & 45 & 37 & 0 & 5.0 & 51 & 186 & 22 \\
\hline Chikkaballapura & 38 & 4.3 & 55 & 44 & 0 & 4.5 & 40 & 186 & 23 \\
\hline Koppal & 42 & 0.0 & 51 & 45 & 0 & 1.0 & 45 & 184 & 24 \\
\hline
\end{tabular}




\begin{tabular}{|c|c|c|c|c|c|c|c|c|c|}
\hline 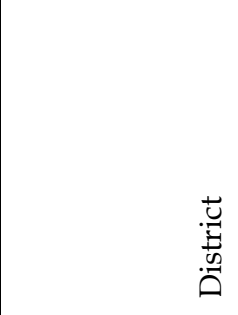 & 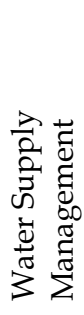 & 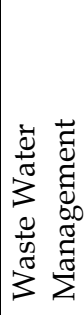 & 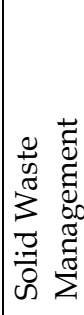 & 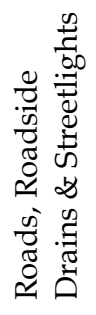 & 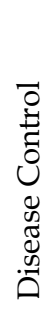 & 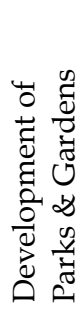 & 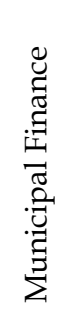 & 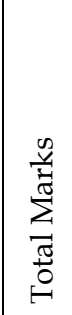 & $\begin{array}{l}\underline{v} \\
\widetilde{\Xi} \\
\widetilde{\simeq}\end{array}$ \\
\hline Chamarajnagar & 46 & 4.0 & 55 & 42 & 0 & 3.0 & 33 & 182 & 25 \\
\hline Kolar & 29 & 1.7 & 56 & 40 & 0 & 3.2 & 50 & 179 & 26 \\
\hline Gulbarga & 33 & 2.0 & 58 & 39 & 0 & 2.2 & 40 & 174 & 27 \\
\hline $\begin{array}{l}\text { Bangalore } \\
\text { Urban }\end{array}$ & 24 & 0.0 & 60 & 40 & 0 & 0.0 & 41 & 165 & 28 \\
\hline Bidar & 37 & 0.0 & 57 & 40 & 0 & 2.7 & 24 & 160 & 29 \\
\hline Yadgir & 44 & 0.0 & 44 & 35 & 0 & 3.5 & 31 & 158 & 30 \\
\hline
\end{tabular}

Note: BBMP has been excluded in the study.

Source: Computed from the data available onhttp://karbenchmarking.gov.in

In table 4, information related to inter-ULB imbalances has been presented. Among the districts Bagalkot, Udupi, Chikkamagalur, Gulbarga and Chikkaballapur have higher inter-ULB imbalances. A point to be notedhere is that out of these five districts, Mysore division has 2 districts and remaining three division have one district each. It means inter-ULB imbalances are high in Mysore division. On the other hand districts like Kolar, Dharwad, Shimoga, Gadag and Ramanagar have shown lower imbalances. Out of these five districts, 2 districts are from Belgaum division, and remaining three districts are from Bangalore division. None of the districts are from Mysore as well as from Gulbarga divisions. Among the sectors Development of Parks \& Gardens and Waste Water Management have higher inter-ULB imbalances in all the districts. Lower imbalances are observed in Solid Waste Management and Municipal Finance in most of the districts comparatively. 
Table 4: District wise Inter-ULB Imbalances in Urban Service Level Benchmarking, 2009-2010 (CV-\%)

\begin{tabular}{|c|c|c|c|c|c|c|c|c|}
\hline 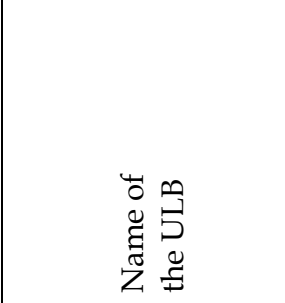 & 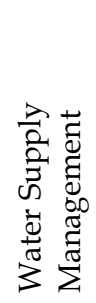 & 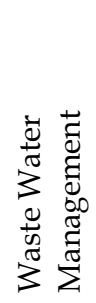 & 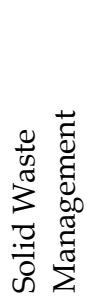 & 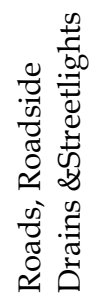 & 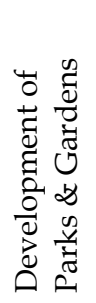 & 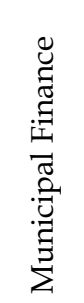 & 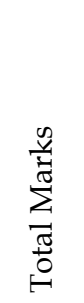 & 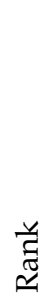 \\
\hline Bagalkot & 16.9 & 159.1 & 28.3 & 24.0 & 266.3 & 50.0 & 25.2 & 1 \\
\hline Udupi & 30.4 & 116.4 & 34.0 & 15.8 & 90.4 & 9.8 & 23.1 & 2 \\
\hline Chikkamagalur & 23.7 & 282.8 & 44.3 & 6.6 & 77.7 & 42.7 & 22.6 & 3 \\
\hline Gulbarga & 34.5 & 212.1 & 41.6 & 36.2 & 130.8 & 41.9 & 21.8 & 4 \\
\hline Chikkaballapur & 28.1 & 161.0 & 28.8 & 27.4 & 134.6 & 45.1 & 21.2 & 5 \\
\hline Koppal & 38.5 & .. & 13.3 & 4.8 & 200.0 & 41.7 & 19.8 & 6 \\
\hline Tumkur & 21.8 & 316.2 & 18.2 & 21.6 & 126.0 & 48.4 & 18.6 & 7 \\
\hline Mysore & 17.9 & 156.6 & 16.0 & 24.5 & 114.2 & 30.1 & 17.7 & 8 \\
\hline Bangalore Rural & 13.2 & 223.6 & 24.3 & 15.9 & 104.6 & 24.6 & 17.4 & 9 \\
\hline Hassan & 14.6 & 86.2 & 27.9 & 20.9 & 190.0 & 14.1 & 17.0 & 10 \\
\hline Bidar & 25.0 & .. & 7.9 & 33.9 & 122.5 & 42.6 & 16.9 & 11 \\
\hline Haveri & 27.4 & 282.8 & 24.9 & 21.5 & 222.7 & 38.8 & 16.6 & 12 \\
\hline Chamarajanagar & 33.2 & 223.6 & 24.5 & 34.2 & 223.6 & 37.3 & 16.0 & 13 \\
\hline Bellary & 27.6 & 221.3 & 29.1 & 25.3 & 123.6 & 46.4 & 14.7 & 14 \\
\hline Belgaum & 17.0 & 273.3 & 29.8 & 10.2 & 230.7 & 24.8 & 14.1 & 15 \\
\hline Raichur & 22.6 & 244.9 & 27.2 & 34.4 & 244.9 & 13.5 & 13.7 & 16 \\
\hline Bijapur & 25.9 & 154.9 & 23.4 & 24.1 & .. & 36.6 & 13.7 & 17 \\
\hline Mandya & 10.0 & 155.7 & 16.4 & 24.0 & 49.3 & 32.5 & 13.5 & 18 \\
\hline Yadgir & 1.1 & .. & 20.6 & 45.1 & 117.8 & 28.5 & 13.4 & 19 \\
\hline Chitradurga & 27.2 & 244.9 & 14.1 & 10.2 & 118.0 & 31.9 & 12.8 & 20 \\
\hline Kodagu & 27.6 & .. & 10.3 & 17.5 & 200.0 & 15.1 & 11.9 & 21 \\
\hline Dakshina Kannada & 24.9 & 198.4 & 20.8 & 18.0 & 101.5 & 26.8 & 11.7 & 22 \\
\hline Uttara Kannada & 36.0 & 237.1 & 12.7 & 7.9 & 99.7 & 22.2 & 10.8 & 23 \\
\hline Davangere & 13.0 & 215.5 & 14.3 & 11.3 & 159.5 & 10.9 & 10.6 & 24 \\
\hline Kolar & 28.4 & 244.9 & 14.9 & 9.8 & 189.9 & 25.7 & 10.1 & 25 \\
\hline Dharwad & 17.6 & 155.9 & 20.7 & 16.8 & 154.9 & 28.4 & 9.9 & 26 \\
\hline Shimoga & 15.6 & 300.0 & 14.8 & 18.9 & 96.6 & 23.7 & 8.9 & 27 \\
\hline Gadag & 19.3 & 200.0 & 18.2 & 17.8 & 101.8 & 25.8 & 7.0 & 28 \\
\hline Ramanagar & 4.6 & 135.0 & 9.9 & 17.2 & 200.0 & 10.3 & 4.2 & 29 \\
\hline
\end{tabular}

Note: Bangalore Urban district has been excluded.So only one ULB has been considered for the district.

Source: Computed from the data available on http://karbenchmarking.gov.in 


\section{Service Level Benchmarking of Different Levels of ULBs:}

In Table 5 different category wise urban service level benchmarking has been presented. It is observed that higher the level of urban local body, higher is the score in benchmarking. City Corporations have the highest average score/marks of 259, which is 48 per cent of achievement as against the total marks of 540.Average score of the City Municipal Councils are 218 (40\%), which is the second highest. Town Municipal Councils (204 marks) and Town Panchayats (207 marks) have more are less the same level $(38 \%)$ of achievement.

Table 5: Average Urban Service Level Benchmarking by type of ULBiii 2009-2010

\begin{tabular}{|c|c|c|c|c|c|c|c|c|c|}
\hline 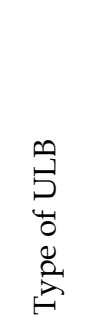 & 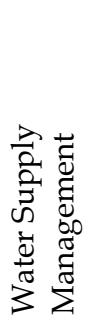 & 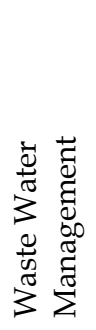 & 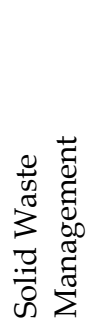 & 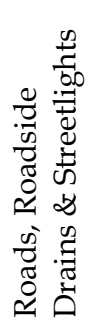 & 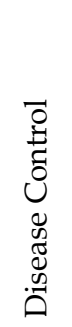 & 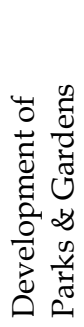 & 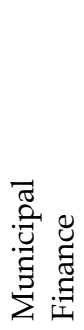 & 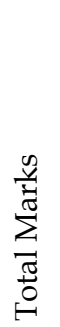 & å \\
\hline $\mathrm{CC}$ & 63.43 & 15.86 & 68.57 & 41.86 & 0.00 & 5.14 & 64.43 & 259 & 48 \\
\hline CMC & 49.25 & 5.50 & 61.61 & 44.66 & 0.00 & 3.64 & 53.34 & 218 & 40 \\
\hline TMC & 45.34 & 3.29 & 59.43 & 43.77 & 0.00 & 4.02 & 48.17 & 204 & 38 \\
\hline $\mathrm{TP}$ & 48.12 & 0.00 & 58.27 & 48.27 & 0.00 & 3.60 & 48.88 & 207 & 38 \\
\hline
\end{tabular}

Source: Computed from the data available on http://karbenchmarking.gov.in

Except in Roads, Roadside Drains $\mathcal{E}$ Streetlights in all other sectors, average performance of CC is higher than other categories of ULBs. In this sector average performance of TPs is the highest. A point to be noted here is that average score in Waste Water Management of TPs is zero out of a maximum score of 50. Totally, it is found that higher the level of ULB, higher will be the performance in benchmarking. Hence, the trends in the lines are showing downward trend from higher ULB to lower ULB (please see graph 1). 


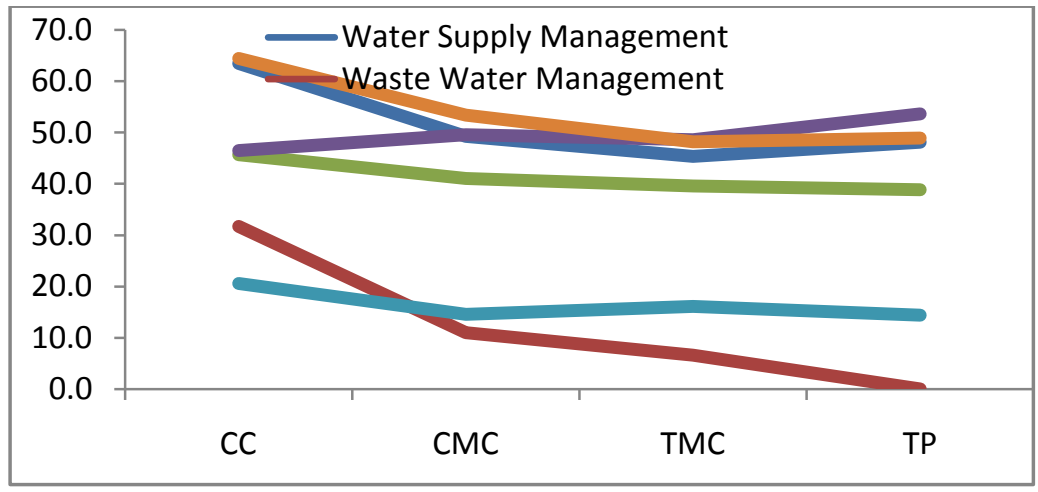

Graph 1: Performance of Urban Service Level Benchmarking by type of ULB 2009-2010 (\%) Source: Computed from the data available on http://karbenchmarking.gov.in

Table 6: Service Level Benchmarking of City Corporations, 20092010

\begin{tabular}{|c|c|c|c|c|c|c|c|c|c|c|c|}
\hline 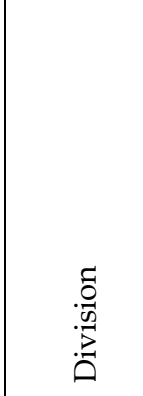 & 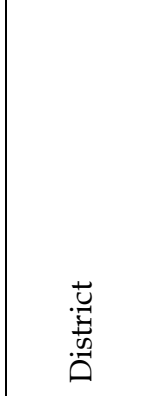 & 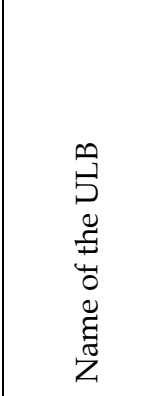 & 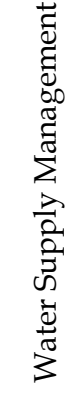 & 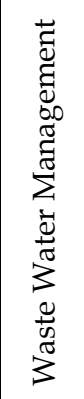 & 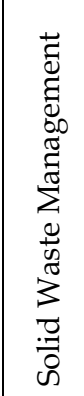 & 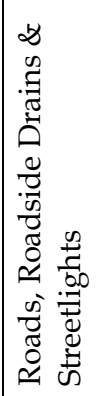 & 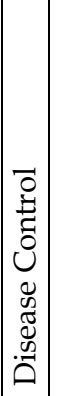 & 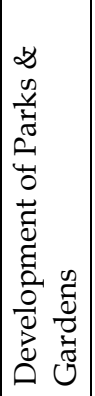 & 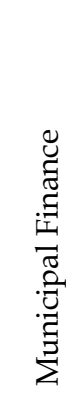 & 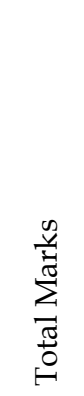 & 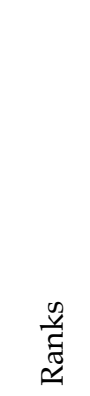 \\
\hline Mysore & Mysore & Mysore & 71 & 26 & 96 & 56 & 0 & 4 & 81 & 334 & $1(3)$ \\
\hline Mysore & $\begin{array}{l}\text { Dakshina } \\
\text { Kannada }\end{array}$ & Mangalore & 74 & 14 & 70 & 44 & 0 & 8 & 70 & 280 & $2(10)$ \\
\hline Belgaum & Belgaum & Belgaum & 57 & 14 & 88 & 52 & 0 & 0 & 53 & 264 & $3(16)$ \\
\hline Belgaum & Dharwad & \begin{tabular}{|l} 
Hubli- \\
Dharwad
\end{tabular} & 63 & 10 & 59 & 47 & 0 & 4 & 67 & 250 & $4(29)$ \\
\hline \begin{tabular}{|l} 
Bangalore \\
\end{tabular} & Davangere & Davangere & 68 & 17 & 61 & 37 & 0 & 12 & 53 & 248 & $5(34)$ \\
\hline Gulbarga & Gulbarga & Gulbarga & 57 & 12 & 66 & 25 & 0 & 8 & 59 & 227 & $6(64)$ \\
\hline Gulbarga & Bellary & Bellary & 54 & 18 & 40 & 32 & 0 & 0 & 68 & 212 & $7(102)$ \\
\hline \multicolumn{3}{|c|}{ CV (\%) } & 12.24 & 33.06 & 27.31 & 26.51 & & 86.54 & 15.72 & 15.37 & \\
\hline
\end{tabular}

Note: Figures in the parenthesis are ranks to the total ULBs in Karnataka

Source: Computed from the data available on http://karbenchmarking.gov.in

In table 6 service level benchmarking for City Corporations have been presented. There were only seven City Corporations in 
Karnataka during 2009-10. Out of this, Bangalore division had only one CC while remaining three divisions had each two CCs. Top two CCs are from Mysore division and bottom two CCs are from Gulbarga division. Mysore (334 marks) and Bellary (212 marks) are the top and bottom CCs in the state respectively. To find out the inter-ULB variations, coefficient of variation has been calculated and presented at the bottom of the table. It is found that among the sectors Development of Parks $\mathcal{E}$ Gardens (CV-86.54 \%) has the highest variation followed by Waste Water Management (CV-33.06\%). On the other hand Water Supply Management (CV-12.31\%) has the lowest imbalances.

In Graph 2 marks obtained by city municipal councils (CMCs) in service level benchmarking has been presented. Bar graph shows the actual marks, while line graph shows the percentages. It is found that out of $44 \mathrm{CMCs}$ only five CMCs have obtained more than 250 marks out of 450 marks in benchmarking. These top five CMCs are Udupi, Gokak, Shimoga, Tumkur and Jamakhandi. The benchmarking score of these five CMCs are below 170 they are Shahabad, Basavakalyan, Doddaballapur, Mulabagal and Robertsonpet. In the appendix table 1 different sector wise benchmarking has been provided for different CMCs of Karnataka State.

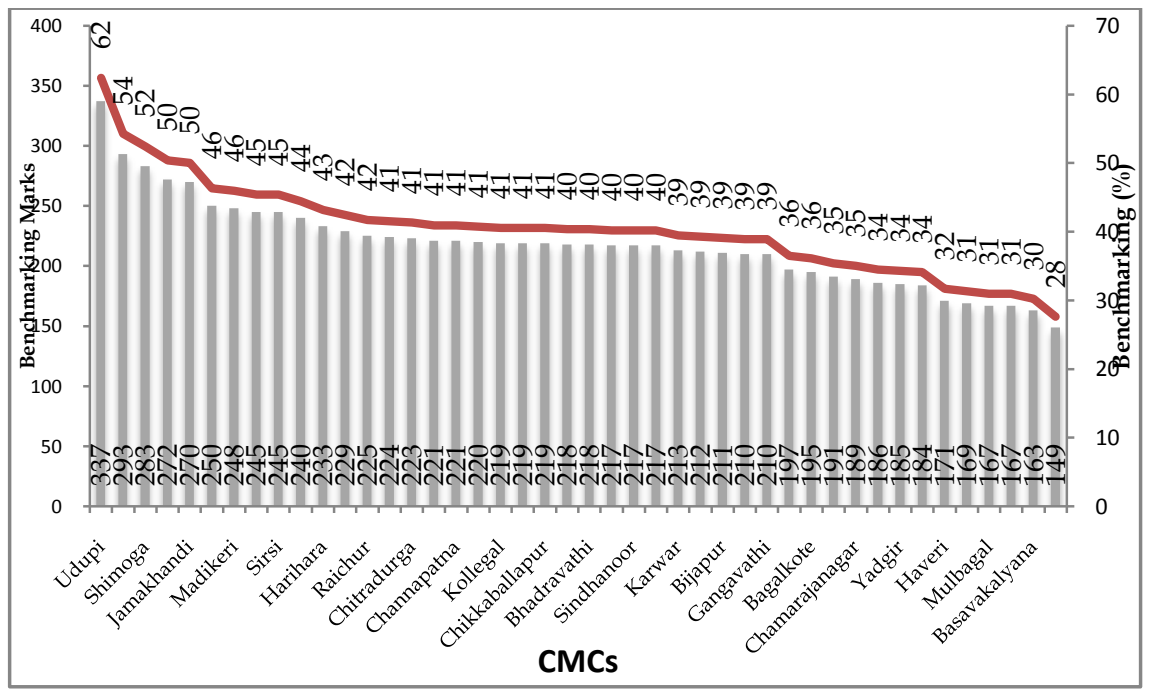

Graph 2: Service Level Benchmarking of City Municipal Councils, 2009-2010 
It is observed from the table that-

- Through Udupi, Gokak, Shimoga, Tumkur and Jamakhandi were in the top position (among the CMCs) in overall ranking, their performance in Development of Parks $\mathcal{E}$ Gardens is not satisfactory

- In overall ranking Doddaballapur is in the bottom third position but its performance in Municipal Finance is in the $15^{\text {th }}$ position, which is in the satisfactory position

- Ilkal found in the 32nd position in overall performance out of 44 CMCs, while it is found in the first position in Waste Water Management sector.

- Among the sectors Waste Water Management and Development of Parks and Gardens have higher inter-ULB variation than other sectors.

- Except, five CMCs none of the CMCs have achieved the benchmarking more than 50 per cent in the state

- $17 \mathrm{CMCs}$ out of $44 \mathrm{CMCs}$ in the state have the benchmarking only less than 40 per cent.

- 25 out of $44 \mathrm{CMCs}$ have not shown any score in Waste Water Management. And 20 CMCs marks in Development of Parks $\mathcal{E}$ Gardens is zero

In graph 3 performances of Town Municipal Corporations (TMCs) in benchmarking have been presented. It is observed that out of 95 TMCs only five TMCs have achieved more than 50 per cent of service level bench marking namely, Kundapur, Karkala, Mudhol, Bhatkal and Holenarsipura. On the other hand Shidlaghatta, Chittapur and Taredal these TMCs have less than 25 per cent of achievement.

- 57 out of 95 TMCs have not achieved even 40 per cent of benchmarking.

- In case of Waste Water Management 72 out of 95 TMC have not scored any marks.

- 54 TMCs have obtained zero marks in Development of Parks $\mathcal{E}$ Gardens.

- Karkala, Mudhol, Bhatkal, Athani, Shrirangapatna andChannarayapatna have shown good performance in overall benchmarking but their performance is not satisfactory in Roads, Roadside Drains E Streetlights 
- Malavalli, Shiggon, Kunigal, Kolar and Shiralkoppa these TMCs have shown good performance in Development of Parks $\mathcal{E}$ Gardens, though these TMCs have not shown better performance in overall benchmarking.

- Though Shidlaghatta is in $93^{\text {rd }}$ position in overall benchmarking but found in the $9^{\text {th }}$ position out of 95 TMCs in Waste Water Management. Similarly, Guledgudda has found in $74^{\text {th }}$ position in overall performance, while its ranking is in $3^{\text {rd }}$ position in Waste Water Management.

At the end of the table CV (\%) has been presented. It is observed that Waste Water Management and Development of Parks \& Gardens have higher inter-TMC imbalances than other sectors (please see appendix table 2)

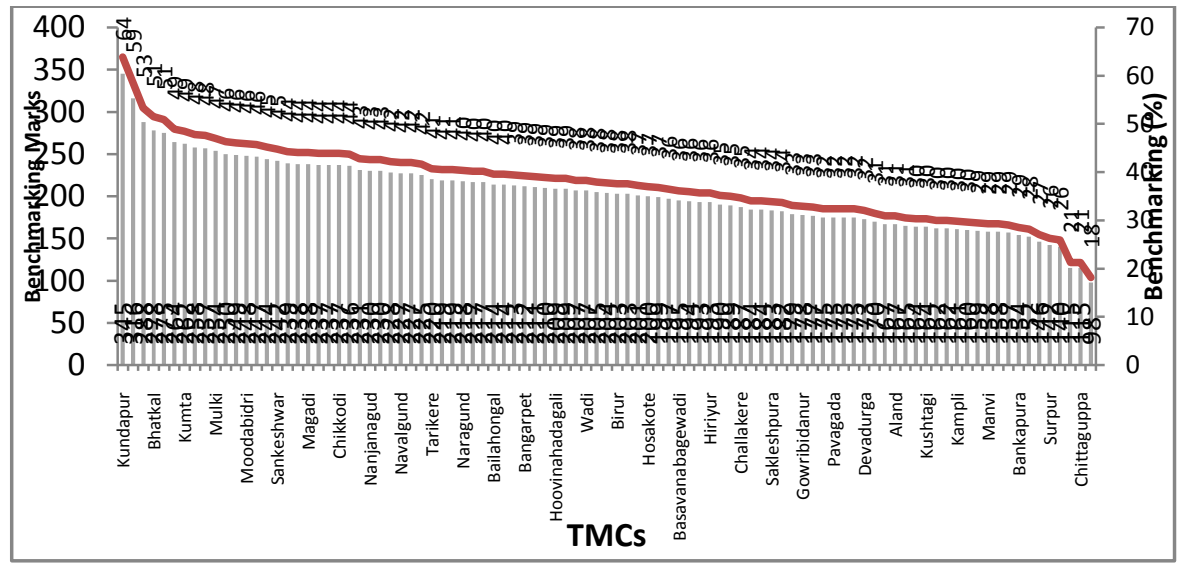

Graph 3: Service Level Benchmarking of Town Municipal Corporations (TMCs), 2009-2010 Source: Computed from the data available onhttp://karbenchmarking.gov.in In graph 4 service level benchmarking of Town Panchayaths (TPs) has been depicted. In this graph actual marks as well as percentage of achievements have been presented. It is observed that out of 67 TPs in the state only two TPs namely Koppa and Shringeri have achieved more than 50 per cent of benchmarking. 41 (61\%) TPs have achieved less than 40 per cent of service level benchmarking. Koppa, Shringeri, Haliyal, Hunagund and T. Narsipur are found in the top five performing TPs in the state, while Molakalmur, Kudligi, Yelburga, Hanur and Jewargi are in the bottom position in service level benchmarking. 
- Though Koppa, Haliyal, Kalgatagi and Hosanagara were in the top position in overall benchmarking, their performance in Water Supply Managementis not at a satisfactory level.

- Shringeri, Tirthahalli Hosanagara, Piriyapatna and Kushalanagara have not shown good score in Solid Waste Management sector, though these TPs have good score in overall service level benchmarking.

- In overall performance, Kundgol and Naregal are at the lower level, but have shown considerable progress in Solid Waste Management.

- Even though TPs like Hungund, T. Narasipura, Kalagatagi, Hosanagara were found in the higher position in overall benchmarking, they exhibit lower performance in Roads, Roadside Drains $\mathcal{E}$ Streetlights. Alternatively, Afzalpur is in the $3^{\text {rd }}$ position in this sector but its overall performance is in $50^{\text {th }}$ rank out of 67 TPs.

- Kudligi is the $64^{\text {th }}$ position in overall benchmarking, while it is found in the $1^{\text {st }}$ position in Development of Parks and Gardens.

At the end of the table CV (\%) has been presented for TPs of the state. It is observed that Development of Parks $\mathcal{E}$ Gardens have higher inter-ULB imbalances than other sectors (please see appendix table 3).

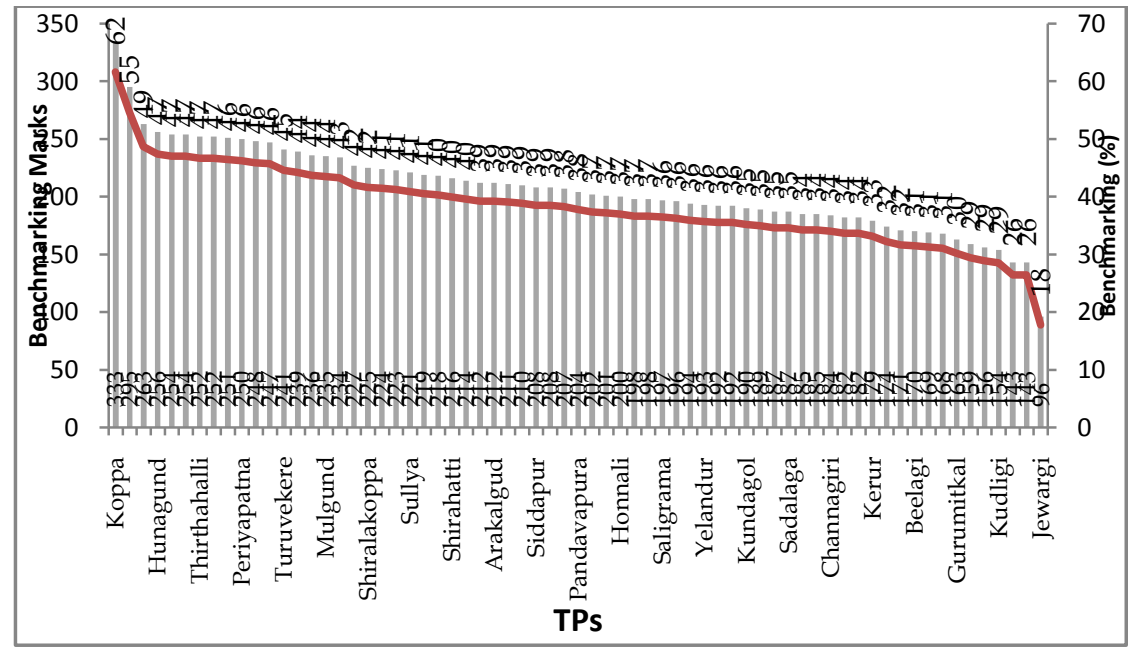

Graph 4: Service Level Benchmarking of Town Panchayats(TPs), 2009-2010 Source: Computed from the data available onhttp://karbenchmarking.gov.in 


\section{Grouping of ULBs based on per capita income and Service Level Benchmarking (SLBM):}

To see the performance in services level benchmarking in comparison with per capita income (PCI) ULBs have been grouped into four categories namely,

\begin{tabular}{|l|l|}
\hline I Best & High SLBM and high PCI \\
\hline II Good (Lopsided SLBM) & High SLBM and LowPCI \\
\hline III Low Lopsided PCI & Low SLBM and High PCI \\
\hline IV Bad & Low SLBM and Low PCI \\
\hline
\end{tabular}

Table 7: Grouping of ULBs based on Per Capita Income and Service Level Benchmarking

\begin{tabular}{|l|l|}
\hline \multicolumn{1}{|c|}{ III } & \multicolumn{1}{|c|}{ I } \\
Siddapur, Hosakote, Saligrama, & Kundapur, Udupi, Mysore, \\
Narasimharajapura, Bagalkote, & Koppa, Karkala, Shringeri, \\
Yelandur, Somwarpet, Ullal, & Shimoga, Mangalore, Tumkur, \\
Shiggaon, Mudigere, Gubbi, & Helgaum, Mulki, Kalagatgi, \\
Srinivasapur, Beelagi, & Moodabidri, Davangere, \\
Robertsonpet, Mulbagal, & Madikeri, Kushalanagara, Puttur, \\
Doddaballapur, Anekal, & Khanapur, Sagar, Sirsi, Jog \\
Devanahalli, Shahapur & Kargal, Vijayapura, Magadi, \\
(19 Taluks) & Annigeri, Belthangadi, Sandur, \\
& Navalgund, Alnavara, Sullya, \\
& Chikmagalur, Nelamangala, \\
& Koppal, Chikkaballapur, \\
& Virajpet, Naragund, Bhadravathi, \\
& Bantwal, Ramanagaram, Karwar, \\
& Arakalgud, Bangarpet, Bellary, \\
& Hunsur \\
& (45 Taluks) \\
\hline
\end{tabular}




\begin{tabular}{|l|l|}
\hline \multicolumn{1}{|c|}{ IV } & \multicolumn{1}{|c|}{ II } \\
Hoovinahadagali, Lingasugur, & Gokak, Mudhol, Bhatkal, \\
Konnur, Mahalingapur, & Holenarsipura, Jamakhandi, \\
Gudibande, Wadi, Indi, & Athani, Haliyal, Kumta, \\
Pandavapura, Sindagi, Birur, & Shrirangapatna, Maddur, \\
Hosadurga, Rayabagh, Mundargi, & Hunagund, T.Narsipur, \\
Saragur, Honnali, Bannur, Ankola, & Hukkeri, Thirthahalli, \\
Chincholi, Ron, Ilkal, & Periyapatna, Hassan, \\
Basavanabagewadi, Ramadurg, & Channarayapatna, K.R.Nagar, \\
Hirekerur, Badami, Hiriyur, & Talikote, Sankeshwar, \\
Tekkalakote, Sira, Malavalli, & Turuvekere, Dandeli, Hanagal, \\
Kundagol, Aurad, & Shikaripura, Chikkodi, \\
Chamarajanagar, Naregal, & Mundagod, Byadgi, Mulgund, \\
Sadalaga, Challakere, Mandya, & Harihara, Kanakapura, \\
Mudagal, Afzalpur, Yadgir, Malur, & Nanjanagud, Belur, Rabkavi \\
Channagiri, Bidar, Sakleshpura, & Banhatti, Honnavar, Gulbarga, \\
Kerur, Kunigal, Gowribidanur, & Lakshmishwara, Raichur, \\
Bagepalli, Mudalagi, Pavagada, & Shiralakoppa, Harappanahalli, \\
Madhugiri, Chittapur, Kamalapur, & Tiptur, Kudachi, Chitradurga, \\
Devadurga, Haveri, Kottur, & Channapatna, Ranebennur, \\
Guledgudda, Koratagere, & Tarikere, Arasikere, Kollegal, \\
Holalkere, Savanur, Aland, & Chintamani, Yellapur, \\
Gundlupet, Kushtagi, & Nippani, K.R.Pet, Sindhanoor, \\
Basavakalyana, Gurumitkal, & Shirahatti, Bailahongal, Kadur, \\
Sedam, Kolar, Kampli, Humnabad, & Jagalur, Gajendragad, Soraba, \\
Alur, Chikkanayakanahalli, Manvi, & Gadag Betegeri, Saundatti, \\
Muddebihal, Molakalmur, & Bijapur, Heggadadevanakote, \\
Bankapura, Kudligi, Shiraguppa, & Nagamangala, Hospet, \\
Shahabad(CMC), Bhalki, Yelburga, & Gangavathi \\
Hanur, Surpur, Shidlaghatta, & (65 Taluks) \\
Chittaguppa, Teradal, Jewargi & \\
(84 Taluks) & \\
&
\end{tabular}

Source: Computed from the data available onhttp://karbenchmarking.gov.in

Information related to this has been presented in table 7. Region and division has number and percentages of ULBs in different category has been presented in appendix table 4 . Further a scatter diagram has also been prepared and presented in graph 5 for meaningful analysis. From these tables and graphs it is clear that more proportion of ULBs from North Karnataka (51\%) in general and Hyderabad Karnataka (77\%) in particular are situated in the last group that is lower per capita income and lower service level benchmarking. Contrary to this most of the ULBs from south 
Karnataka (30\%) in general and Mysore division (36\%) in particular are situated in the first group, where higher per capita income and higher service level benchmarking are observed. ULBs like Muddebihal, Molakalmur, Bankapura, Kudligi, Shiraguppa, Shahabad(CMC), Bhalki, Yelburga, Hanur, Surpur, Shidlaghatta, Chittaguppa, Teradal, Jewargishould be given more importance as they are in the last position in both these two indicators

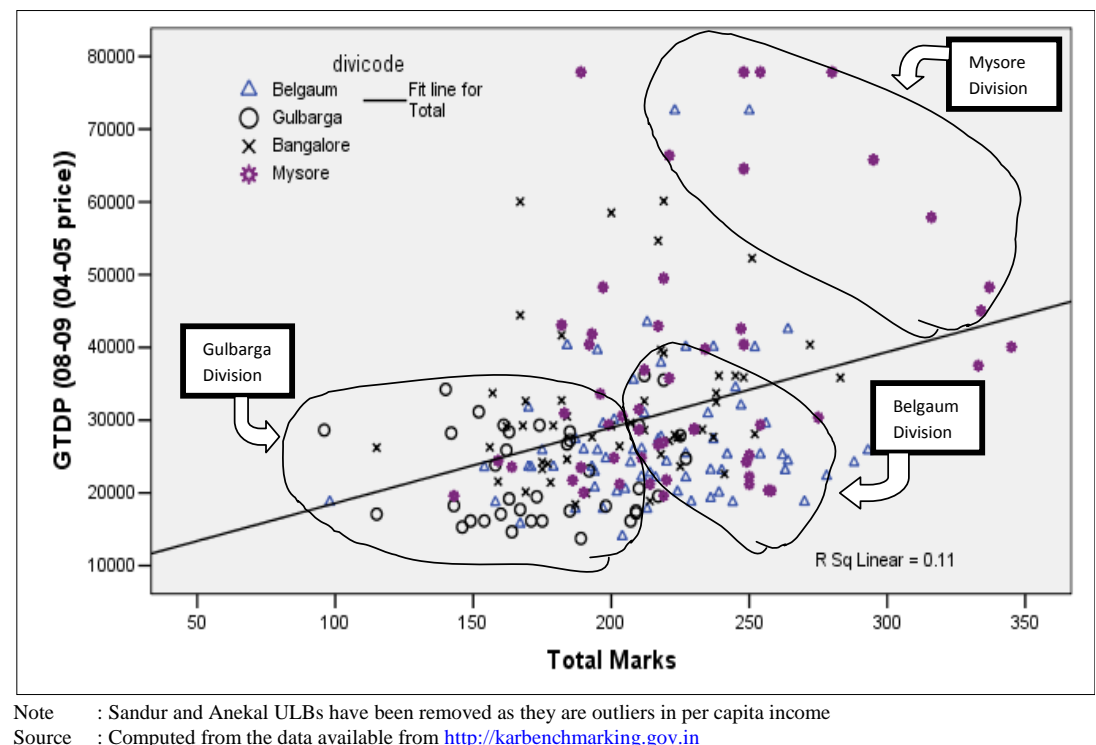

Graph5: Scatter diagram of ULBs in Karnataka

Table 8: Correlation Matrix of different service level benchmarking and per-capita income

\begin{tabular}{|l|c|c|c|c|c|c|c|c|}
\hline & I1 & I2 & I3 & I4 & I5 & I6 & I7 & I8 \\
\hline I1 & 1 & & & & & & & \\
\hline I2 & $.190^{* *}$ & 1 & & & & & & \\
\hline I3 & $.245^{* *}$ & 0.081 & 1 & & & & & \\
\hline I4 & $.185^{* *}$ & -0.088 & $.204^{* *}$ & 1 & & & & \\
\hline I5 & $.135^{*}$ & 0.103 & 0.108 & 0.082 & 1 & & & \\
\hline I6 & $.309^{* *}$ & $.161^{*}$ & $.184^{* *}$ & $.301^{* *}$ & 0.071 & 1 & & \\
\hline I7 & $.657^{* *}$ & $.315^{* *}$ & $.639^{* *}$ & $.521^{* *}$ & $.284^{* *}$ & $.717^{* *}$ & 1 & \\
\hline I8 & $.250^{* *}$ & 0.058 & 0.064 & $.227^{* *}$ & 0.107 & $.333^{* *}$ & $.332^{* *}$ & 1 \\
\hline
\end{tabular}

Note: $\quad * *$ Correlation is significant at the 0.01 level (2-tailed).

* Correlation is significant at the 0.05 level (2-tailed). 
I1- Water Supply Management, I2- Waste Water Management, I3- Solid Waste Management, I4Roads, Roadside Drains \& Streetlights, I5- Development of Parks \& Gardens, I6- Municipal Finance, I7- Total Marks, I8- GTDP (08-09 (04-05 prices))

\section{Findings of the Study:}

\section{Region and Division-wise Performance:}

- Only39 per cent of bench marking has been achieved in the state.

- Among the sectors, benchmarking is good in Roads, Roadside Drains $\mathcal{E}$ Streetlights (45 marks with 50\%) and Municipal Finance (50 marks with 50\%).Water supply (48 marks with $48 \%$ ) and solid waste management (60 marks with $40 \%$ ) and Municipal Finance (50 marks with 50\%) have also shown good performance comparatively.

- Lower performance is observed in the sectors like Waste Water Management (3 marks with 6\%) and Development of Parks $\mathcal{E}$ Gardens (4 marks with 15\%).

- In Disease Control noneof the ULBs have got a score above zero in the state

- Between the regions, southern region is in a better-off condition with 217 marks as compared to the northern region which has 202 marks.

- Among the divisions, Mysore division is in the first position with the average marks of 230 followed by Belgaum (217 marks) and Bangalore (204 marks). The lowest marks are obtained by Gulbarga (177) division.

- Except Solid Waste Management, the remaining sectors in Mysore division are found to be in the first position. Gulbarga division is found to be in the last position in all seven sectors.

- Among the sectors, Waste Water Management (207) has the highest inter-ULB variation in benchmarking followed by Development of Parks $\mathcal{E}$ Gardens (137). Bothsouth and north have a similar inter-ULB variation in benchmarking. 
- Northern region has huge inter-ULB imbalances in Waste Water Management and Development of Parks $\mathcal{E}$ Gardens as compared to the southern region.

- In overall benchmarking Mysore division has the highest imbalances followed by Gulbarga and Bangalore. The lowest imbalances are observed in Belgaum division. All the division have higher inter-ULB variation, Waste Water Management and Development of Parks \& Gardens.

- It is found that higher the level of urban local body, higher is the score in benchmarking. City Corporations have the highest average score/marks of 259, which is 48 per cent of achievement as against the total marks of 540.Average score of City Municipal Councils is 218 (40\%), which is the second highest. Town Municipal Councils (204 marks) and Town Panchayats (207 marks) have more are less the same level (38\%) of achievement.

\section{District-wise Performance:}

- Even though, Shimoga district is in the second position in overall benchmarking, its performance is not satisfactory in Waste Water Management (19th rank) and Solid Waste Management (10 th rank).

- In overall benchmarking Chamarajanagar district is in the 25th rank, however its performance in Waste Water Management ( $7^{\text {th }}$ rank) is quite good.

- Due to lower performance in parameterslike Development of Parks $\mathcal{E}$ Gardens (11 th rank) and Municipal Finance (12 th rank), Mysore district was pushed to the third position instead of second position.

- Hassan (1strank) and Bagalkot (3rdrank) districts have shown good performance in Waste Water Management, even thoughtheir rankings are $11^{\text {th }}$ and $15^{\text {th }}$ respectively in overall benchmark.

- In overall benchmarking Yadgir district found in the bottom position, but its performance in Development of Parks $\mathcal{E}$ Gardens is comparatively good with $12^{\text {th }}$ rank. 
- None of the districts from Hyderabad Karnataka are found either in top 5 or even in 10 positions among the 30 districts of Karnataka.

- Among the districts Bagalkot, Udupi, Chikkamagalur, Gulbarga and Chikkaballapur have higher inter-ULB imbalances.

- Kolar, Dharwad, Shimoga, Gadag and Ramanagar have all shown lower imbalances.

- Among the sectors Development of Parks $\mathcal{E}$ Gardens and Waste Water Management have higher inter-ULB imbalances in all the districts. Lower imbalances are observed in Solid Waste Management and Municipal Finance in most of the districts comparatively.

\section{Performance of CCs}

- Among the seven CCs top two CCs are from Mysore division and bottom two CCs are from Gulbarga division.

- Mysore (334 marks) and Bellary (212 marks) are the top and bottom CCs in service level benchmarking in the state.

- Within the City Corporations, the highest variance can be noticed among different sectors, viz., Development of Parks $\mathcal{E}$ Gardens (CV-86.54\%), waste water management (CV$33.06 \%)$ and water supply management (CV-12.31\%).

\section{Performance of CMCs}

- Though Udupi, Gokak, Shimoga, Tumkur and Jamakhandi were in the top position in overall ranking, their performance in Development of Parks $\mathcal{E}$ Gardens is not satisfactory

- In overall ranking Doddaballapur is in the bottom third position but its performance in Municipal Finance is in the $15^{\text {th }}$ rank, i.e., in the satisfactory position

- Ilkal came in the $32^{\text {nd }}$ position in overall performance out of 44 CMCs, but is found in the first position in Waste Water Management sector. 
- The sectors Waste Water Management and Development of Parks and Gardens have higher inter-ULB variation than other sectors.

- Only five CMCs have achieved the benchmarking more than 50 per cent in the state

- $17 \mathrm{CMCs}$ out of $44 \mathrm{CMCs}$ in the state have the benchmarking only less than 40 per cent.

- Out of 44 CMCs in Karnataka, 25 CMCs in Waste Water Management and $20 \mathrm{CMCs}$ in Development of Parks $\mathcal{E}$ Gardens have scored Zero marks.

\section{Performance of TMCs}

- Out of 95 TMCs only five TMCs have achieved more than 50 per cent of service level bench marking namely, Kundapur, Karkala, Mudhol, Bhatkal and Holenarsipura. On the other hand Shidlaghatta, Chittapur and Taredal TMCs have less than 25 per cent of achievement.

- 57 out of 95 TMCs have not achieved even 40 per cent of benchmarking.

- In case of Waste Water Management 72 out of 95 TMC have not received any marks.

- 54 TMCs have obtained zero marks in Development of Parks $\mathcal{E}$ Gardens.

- Karkala, Mudhol, Bhatkal, Athani, Shrirangapatna andChannarayapatna have shown good performance in overall benchmarking but their performance is not satisfactory in Roads, Roadside Drains \& Streetlights

- Malavalli, Shiggon, Kunigal, Kolar and Shiralkoppa have shown good performance in Development of Parks $\mathcal{E}$ Gardens, though these TMCs have not shown better performance in overall benchmarking.

- Though Shidlaghatta is in $93^{\text {rd }}$ position in overall benchmarking but found in the $9^{\text {th }}$ position out of 95 TMCs in Waste Water Management. Similarly, Guledgudda has 
found in $74^{\text {th }}$ position in overall performance, while its ranking is in $3^{\text {rd }}$ position in Waste Water Management.

- Waste Water Management and Development of Parks E Gardens have higher inter-TMC imbalances than other sectors

\section{Performance of TPs}

- Outof 67 TPs only two TPs namely Koppa and Shringeri have achieved more than 50 per cent of benchmarking.

- 41 (61\%) TPs have achieved less than 40 per cent of service level benchmarking.

- Koppa, Shringeri, Haliyal, Hunagund and T. Narsipur are found in the top five performing TPs in the state, while, Molakalmur, Kudligi, Yelburga, Hanur and Jewargi are in the bottom position.

- Though Koppa, Haliyal, Kalgatagi and Hosanagara were in the top position in overall benchmarking, their performance in Water Supply Management was not at a satisfactory level.

- Shringeri, Tirthahalli Hosanagara, Piriyapatna and Kushalanagara have not scored good marks in Solid Waste Management sector, though these TPs have good score in overall service level benchmarking.

- In overall performance, Kundgol and Naregal are in the lower level, but have shown considerable progress in Solid Waste Management.

- Even though TPs like Hungund, T. Narasipura, Kalagatagi, Hosanagara were found in the higher position in overall benchmarking,they have shown lower performance in Roads, Roadside Drains \& Streetlights. Contrary to this Afzalpur is in the $3^{\text {rd }}$ rnak in this sector but its overall performance is in $50^{\text {th }}$ rank out of 67 TPs.

- Kudligi is the $64^{\text {th }}$ position in overall benchmarking, while it is found in the 1stposition in Development of Parks and Gardens. 


\section{Economic Growth and Service Level Benchmarking}

- More the proportion of ULBs from North Karnataka in general and Hyderabad Karnataka in particular are situated in the last group that is lower per capita income and lower service level benchmarking. Contrary to this most of the ULBs from south Karnataka in general and Mysore division in particular are situated in the first group, where higher per capita income and higher service level benchmarking are observed.

- ULBs like Muddebihal, Molakalmur, Bankapura, Kudligi, Shiraguppa, Shahabad, Bhalki, Yelburga, Hanur, Surpur, Shidlaghatta, Chittaguppa, Teradal, Jewargishould be given more importance as they are in the last position in per capita income and service level benchmarking.

\section{Conclusion:}

NorthKarnataka in general and Hyderabad Karnataka in particular are under developed in urban service level benchmarkinglike most of the sectors in the state. Hence, special attention is to be paid for this region both in planning and allocation of money. In addition to this, a monitoring mechanism should be set up for this region so that more funds can be mobilised and utilised for the speedy development of this region. Along with this, political will and commitment should be there in the party which is in power at the state level. A deadline has to be fixed for higher allocation for under developed regions to reach the average level in benchmarking. After the completion of a stipulated time, allocation should be fixed on the basis of their achievements. Higher allocation should be given to those ULBs, which have achieved higher performance in provision of the services.

More powers should be given to Urban Local Bodies and its elected representatives. Further, a monitoring mechanism should be set up in lower performing sectors so that targets can be achieved. Along with higher allocation for higher performing ULBs. Incentives, rewards and promotions should be given to the concerned staff as well as people's representatives. Targets should be like - 24 hours water supply for 30 per cent of households of the city, 60 per cent of 
drainage connections, 100 per cent of all-weather roads for all wards and so on. Such practices will lead to aBALANCED REGIONAL DEVELOPMENTin the URBAN SECTOR.

\section{References:}

Aziz Abdul and Hanagodimath Shiddalingaswami (2010) Implementation of D. M. Nanjundappa Committee Recommendations for Redressal of Regional Imbalance, CMDR Monograph -58

Chandrashekar H and Nagaraju S. (1999):"Regional Pattern of Agriculture Development in Karnataka" in Srinivas Gowda M.V. and Nanje Gowda (ed.) Economic Evelopment of Karnataka: Leading Issues, (Bangalore: Local Advisory Committee, 81 Annual Conference of the Indian Economic Association)

Chandrashekar T R (2009) Janarannu Olagolluva Abhirudhi: Hyderabad Karnataka Region, Prasaranga, Kannada University, Humpi.

Chandrashekar T R (2014) Budgets of Regional Social Justice an Inquiry into the Recent Budgets of Karnataka, XI Annual Conference of Karnataka Economic Association, 21-22 March

Dadibhavi R V (1982) "An Analysis of Inter-Taluka Disparity in Backwardness in Karnataka State, 1975-76", Indian Journal of Regional Sciences Vol XIV, No. 2

Dadibhavi R V (1998), “Disparities in Development of NorthKarnataka", Indian Journal of Regional Studies, Vol. XXX No 2

Degaonkar C K (2001) Human Development in Backward Region-A Micro View, Gulbarga University Research Journal, June

Degaonkar C K (2014) Promoting Human Development in Hyderabad Karnataka Region: Agenda before 371(J), XI Annual Conference of Karnataka Economic Association, 21-22 March

Deshpande and Dadibhavi R V (2005), "Regional Imbalances and Economic Growth in Karnataka, paper presented at the Seminar on Regional Development in India, Institute for Human Development, New Delhi. 
Deshpande R S (2014) Political Economy of Regional Development in Karnataka, XI Annual Conference of Karnataka Economic Association, 21-22 March

Gayatri (2012) “District level NRHM Funds Flow and Expenditure: Sub National Evidence from the State of Karnataka", Working paper 278, Institute of Social and Economic Change, Bangalore.

Gayithri (1999) "Role of Infrastructure in Industrial Development of Karnataka: A district level analysis "in Srinivas Gowda M.V. and Nanje Gowda (ed.) Economic Development of Karnataka: Leading Issues, (Bangalore: Local Advisory Committee, 81 Annual Conference of the Indian Economic Association)

Hanagodimath Shiddalingaswami V (2014) "Regional Imbalances in Karnataka and Its Redressal", XI Annual Conference of Karnataka Economic Association, 21-22 March

HPCFRRI (2002): High Power Committee on Redressal of Regional Imbalances in Karnataka (D M Nanjundappa Committee), Government of Karnataka. http://karbenchmarking.gov.in

Kadekodi Gopal K, Kanbur Ravi and Rao Vijayendra et (2008) Development in Karnataka: Challenges of Governance, Equity and Empowerment, Academic Foundation, New Delhi

Nanjunhdappa D M (1999), "Karnataka's Economy: Retrospect and Prospects"in Srinivas Gowda M.V. and Nanje Gowda (ed.) Economic Development of Karnataka: Leading Issues, (Bangalore: Local Advisory Committee, 81 Annual Conference of the Indian Economic Association).

Panchamuchi P R (2001) North, South Divide Karnataka's Development Scenario, CMDR Monograph No. 21, Centre for Multi-disciplinary Development (CMDR), Dharwad, Karnataka Shiddalingaswami H and Ragavendra V K (2010) "Regional Disparities in Karnataka: A District Level Analysis of Growth and Development", CMDR Monograph-60

Smriti Chand () 11 Major Problems of Urbanisation in India, http:/ / www.yourarticle library.com (viewed on 28-14-15)

United Nations (2014) World Urbanization Prospects, United Nations 


\section{Endnotes}

i Due to inter-state disparity/imbalances, under developed regions are fighting for separation of states. Recently Andhra Pradesh has been divided into Telangana and Simandra. There is a huge outcry for separation of states especially in Karnataka, Maharashtra and Odisha.

ii In Karnataka to identify the regional imbalances, High Power Committee on Redressal of Regional Imbalances was set up under the chairmanship of late Prof. D M Nanjundappa. The committee using 35 indicators from 5 different sectors identified 114 taluks as backward taluks among 175 taluks of the state.

iiiThe constitution of Municipalities in Karnataka has been done as per the Karnataka Municipality Act, 1964 and Karnataka Municipal Corporations Act, 1976. In Karnataka as on 2015 there are 214 ULBs which have been classified based on their population.

\begin{tabular}{|l|l|l|}
\hline Type of ULB & Population & Number of ULBs \\
\hline City Corporation (CC) & $\begin{array}{l}3,00,000 \\
\text { above }\end{array}$ & $9^{*}$ \\
\hline City Municipal Council (CMC) & 50,000 to $3,00,000$ & 43 \\
\hline Town Municipal Council (TMC) & 20,000 to 50,000 & 94 \\
\hline Town Panchayat TP & 10,000 to 20,000 & 68 \\
\hline
\end{tabular}

*Tumkur has been recently upgraded to CC. 